\title{
Water companies in Polish law
}

\section{Spótki wodne w prawie polskim}

\author{
http://dx.doi.org/10.12775/PYEL.2015.006
}

\begin{abstract}
In Polish law water companies are regulated by the Water Law Act of 18th July 2001. The water companies have characteristics which can make them efficient tools to solve particular problems of water economy, not only in local or regional range, but also countrywide or even internationally. Taking into consideration the objectives, for which water companies are created, they constitute a topic which could be very interesting for the society.

The object of this research is to present selected regulations concerning the functioning of water companies under Polish law. Firstly, a definition of the water company in the operating law will be presented. Secondly, the legal regulations concerning creation, organisation and termination of water companies, as well as the regulations concerning the supervision of the water companies, will be discussed.
\end{abstract}

Key words: Water companies; water law.

Legal Adviser, Member of Local Government Appellate Board (Samorządowe Kolegium Odwoławcze). 


\section{Streszczenie}

W prawie polskim spółki wodne regulowane są ustawą z dnia 18 lipca 2001 r. Prawo wodne. Spółki wodne posiadają cechy, które mogą z nich czynić skuteczne narzędzia dla rozwiązywania konkretnych problemów gospodarki wodnej w skali nie tylko lokalnej czy regionalnej ale również ogólnokrajowej czy nawet międzynarodowej. $Z$ uwagi na cele, dla których są tworzone, spółki wodne stanowią podmiot, który mógłby się cieszyć znacznym zainteresowaniem a wręcz zaangażowaniem społecznym.

Celem niniejszego opracowania jest przedstawienie wybranych regulacji dotyczących funkcjonowania spółek wodnych w prawie polskim. Przedstawiona zostanie definicja spółki wodnej w obowiązującym prawie. Następnie przedstawione i rozwinięte zostaną regulacje prawne dotyczące tworzenia, organizacji i rozwiązania spółek wodnych jak również regulacje dotyczące nadzoru nad spółkami wodnymi.

Słowa kluczowe: Prawo wodne; spółki wodne.

\section{Introductory issues}

The traditions associated with water companies in Poland go back to Medieval Times. They were associated with the development of the hydro-technical culture, started by the Dutch inhabiting the Pomeranian region. However, its most dynamic development began in the middle of the 19 th century ${ }^{1}$.

Water companies were introduced into Polish legislation with the Water Act of 19 September $1922^{2}$. Its altered content also appeared in the following acts, namely, the Water Law of 30 May $1962^{3}$ and the Water Law of 24 October 1974 .

The Water Act of 1922 stated a broadly developed basis for creation, organisation and functions of water companies. The Act defined

1 R. Paczuski, Spótki wodne. Historia. Podstawy prawne dziatania. Nowe tendencje, Warszawa 1989 , p. 15 et seq.

2 Journal of Laws of 1922, No 102, item 936.

3 Journal of Laws of 1962, No 34, item 158.

4 Journal of Laws of 1974, No 38, item 230. 
the organizational forms of the economic self-government. The legal basis for the action of water companies were significantly limited by the following acts $^{5}$.

Article 17 of the Constitution of the Republic of Poland of 2 April $1997^{6}$ represented the constitutional basis of the actions of the water companies after major political changes in Poland in 1989. The newly presented regulations allowed for development opportunities for water companies to self-govern the water economy ${ }^{7}$.

The constitutional political changes as well as the necessity to adjust the regulations to the requirements of the European Union proved the need to pass a new law. Today, water companies are regulated by the Water Law Act of 18 th July $2001^{8}$.

The object of this research is to present some selected regulations concerning the functioning of water companies under Polish law. Firstly, a definition of the water company in the operating law will be presented. Secondly, the legal regulations concerning creation, organisation and termination of water companies, as well as regulations concerning supervision of water companies will be discussed.

2. The definition and constructional elements of the water company

Constructional elements of a water company are stipulated by article 164 item 1 of the Water Law. According to the given regulation, water companies are referred to as "the organisational forms, which do not act to make a profit, which unite natural or legal persons, aimed to satisfy the needs presented by the regulation, in the area of water management."

In literature, there have been attempts to create a broader definition of the notion.

The notion of the water company has been most broadly defined by J. Rotko, who claims that "it is a form of development of the social activity". $\mathrm{He}$ indicates that the specific characteristics of the water company come from the character of its activity. The water economy is that activity, and is understood as a public good. However, the high level of supervision of public

\footnotetext{
5 R. Paczuski, Spótki wodne - cele, zadania, prawne podstawy organizacji oraz perspektywy ich rozwoju w kontekście zachodzacych zmian, Torun 2006, p. 10 et seq.

6 Journal of Laws of 1997, No 78, item 483 with amendments.

7 R. Paczuski, Spótki wodne - cele, zadania, prawne podstawy organizacji ..., p. 48.

8 Journal of Laws of 2015, item 469 with amendments, consolidated text.

9 J. Sommer in: Prawo wodne. Komentarz, ed. J. Rotko, Wrocław 2002, p. 409.
} 


\section{Katarzyna Wesołowska}

administration, which involves creation, functioning and termination of water companies should be added to the specific characteristics of the water company ${ }^{10}$.

While formulating the definition of the "water company"J. Szachułowicz makes a division of the types of companies into three categories. The first category is the civil law companies. The basis of its action is constituted by the Act of 23 April1964- the Civil Code ${ }^{11}$. The second category is constituted by commercial companies, regulated by the Act of 15 September $2000-$ the Commercial Companies Code ${ }^{12}$. The last category is administrative law companies. Szachułowicz includes in this category, among others, the water companies rules of functioning which were regulated by the Water Law ${ }^{13}$.

As R. Paczuski reasonably points out, the above presented qualifications of a water company as an administrative law company are not known to the science of administrative law and, moreover, do not find justification in the literary output of this science ${ }^{14}$.

Moreover, J. Szachułowicz indicates that "water companies show a big similarity to public companies taking into consideration the tasks conducted by them ${ }^{15 "}$.

According to R. Paczuski, a water company should be defined as an economic self-government organisation for water economy matters ${ }^{16}$.

The definition of a water company defined by B. Rakoczy is considered to be the biggest extent of the content of article 164 item 1 of the Water Law. He defines a water company as "the subject of law, created by the natural and legal persons to fulfil the tasks of the public and legal character, associated with the water economy ${ }^{17}$ ".

The analysis of the definition of a water company, defined in the literature of the water law, concludes that the presented definitions constitute mutual

10 Ibidem.

11 Journal of Laws of 2014, item 121 with amendments, consolidated text.

12 Journal of Laws of 2013, item 1030 with amendments, consolidated text.

13 J. Szachulowicz, Prawo wodne. Komentarz, Warszawa 2013, p. 404, and also M. Kałużny, Prawo wodne. Komentarz, Warszawa 2012, p. 527.

14 R. Paczuski, Spótki wodne - cele, zadania, prawne podstawy organizacji ..., p. 17.

15 J. Szachułowicz, Prawo wodne..., p. 404.

16 R. Paczuski, Prawo ochrony środowiska, Bydgoszcz 2000, p. 291. R. Paczuski, Spótki wodne - cele, zadania, prawne podstawy organizacji ..., p. 16, Wielka encyklopedia prawa, Warszawa 2005, p. 963.

17 B. Rakoczy, in: Prawo wodne. Komentarz, ed. B. Rakoczy, Warszawa 2014, p. 678. 
complementation and elaboration of the very general definition formulated by J. Rotko. The view by J. Szachułowicz should be, however, regarded as incorrect due to the fact that the operating law lacks the basis to distinguish the groups of administrative law.

The objectives, for which a water company can be created, were presented in article 164 item 3 of the Water Law. They involve, in particular, performance, maintenance and exploitation of the devices used to 1) provide water for people (water treatment and supply);2) water pollution protection (wastewater treatment); 3) protection against flooding; 4) agricultural hydraulics and conduction of rational economy at the meliorated areas; 5) water usage for fire-fighting objectives and 6) water sustention.

It is important to highlight, that the above presented catalogue is not closed $^{18}$. In this case water companies can be created also for other objectives, not mentioned in the Act. Of course, the objectives must be aimed to fulfil the tasks of public and legal character, and must be related to a water economy.

Regardless of the fact, that water companies do not exist to make a profit, by article 164 item 2 of the Water Law, the Legislator made an exception from the presented rule. By virtue of this regulation, a water company can act to make a net profit, under the condition that it meets the needs of people united in the area of water management of that water company. However, it is important to emphasise, that the profit made by the water company must be devoted only to its statutory goals ${ }^{19}$.

Moreover, water companies can use financial help coming from public sources. This support is aimed to help finance investments and currently conducted operations connected with the maintenance of water and water devices.

\section{Creation of water companies}

Focusing on the issue concerning the creation of water companies, it is important to show that on the basis of article 165 item 1 of the Water Law, a written agreement of at least two or three natural or legal persons

\footnotetext{
18 Ibidem, p. 681.

19 Ibidem, p. 678.
} 
are needed to create a water company. Regardless of the fact that it is not presented in the indicated regulation, it should be presumed, that also organisational entities without a legal identity, to whom the Legislator has given the legal capacity and towards whom, on the basis of article $33^{1}$ item 1 of the Civil Code, the regulations about the legal persons are used, are part of the agreement concerning the creation of a water company ${ }^{20}$.

Apart from the abovementioned agreement, to create a water company passing of the Statute of a company is also needed, as well as an election of company's authorities. Statute of the company requires a confirmation of a starost (accordingly to the location of a given water company). After the validation of the decision a water company is given legal identity.

Statute of a water company can be defined as a "contractual legal act created by the company founders under the control of the authorities of the public administration. It is the inner act of the company, which controls its creation and determines the rules and duties of its members ${ }^{21}$ ".

The Legislator, in article 166 item 1 of the Water Law, enumerates the elements, which should be obligatorily presented in the content of the Statute. According to the presented regulation, the Statute of a water company particularly defines: 1 ) name and headquarter of a company, as well as area of its activity; 2) objective of a company, as well as means to achieve these objectives; 3 ) norms of establishing the amount of contributions and other services in favour of a company, adequate to objectives of a company; 3a) norms of establishing charges for the water provided, as well as wastewater and draining. In case the activity allowing to make a net profit; 4) rights and duties of members of a company; 5) limitations of the members' right concerning their lands and objects required to fulfil the actions of a company; 6) conditions of accepting new members and dismissing members from a company; 7) conditions of legal succession of a company's members; 8) authorities of a company, its composition, rules of appointment and dismissal, as well as range of activity; 9) the rules of establishing employment within the frameworks of a company; 10) cases requiring calling a general meeting; 11) time of a company valid existence and a way of its termination or liquidation; 12) conditions of imposing obligations, as well as giving authorisation to represent a company; 13) assignment of possession left after termination or liquidation of a company.

B. Rakoczy, in: Prawo wodne..., p. 683.

21 J. Szachułowicz, Prawo wodne..., p. 414. 
The abovementioned obligatory range of regulations stipulated by the Statue, which shall be considered as minimum, should be included in the Statute to consider it as valid. The Statue may contain other regulations, the content of which cannot be defined as an informative system on water housekeeping.

Moreover, the creation of a water company depends on registration of the water cadastre, as it management.

\section{Obligations of the water company}

A water company is responsible for its own obligations with all its assets. These assets are obtained at the moment of the company's creation ${ }^{22}$. The assets consist of fees, donations and objective subsidies from both natural and legal persons, real estates and movables assets, accountancy constituting fixed and current assets ${ }^{23}$.

It is essential to emphasise, that the company's assets should not be associated with the assets of its individual members, who own their separate, individual assets. Thereby, the obligations of the company do not constitute individual obligations of its members ${ }^{24}$.

Moreover, the members of the water company are not responsible for the obligations of the company. These "obligations" should include: civil law, private law, as well as obligations resulting from the responsibility for the members of the company and other subjects that are beyond the company. The above mentioned does not mean, that members of the water company do not take responsibility towards the company, for instance, because of non paid contributions ${ }^{25}$.

The mentioned responsibility does not constitute the contract responsibility ${ }^{26}$, which means that due to the company's obligations, its members cannot be responsible for it.

\footnotetext{
J. Szachułowicz, Prawo wodne..., p. 418.

M. Kałużny, Prawo wodne..., p. 545.

J. Szachułowicz, Prawo wodne..., p. 418.

B. Rakoczy, in: Prawo wodne..., p. 692.

M. Kałużny, Prawo wodne..., p. 546.
} 


\section{Duties of the associates in favour of the water company}

As it has already been presented, various duties are associated with membership in a water company. By article 170 item 1 of the Water Law the Legislator included, among others, the obligation to pay fees - which has its source in the article, as well as the obligation to bear the performances in favour of a company, which source constitutes the Statute of a company. It means, that first of the enumerated obligations is independent of the company's Statute stipulations, and the second comes only when the used obligations are stipulated in $\mathrm{it}^{27}$.

In the range of the amount of contributions bore towards the company by its members, the rule of proportionality was introduced by the Legislator. According to article 170 item 2 of the Water Law, "the amount of the fees and other performances in favour of the water company shall be proportional to the benefits obtained by the members of the company, according to the company's activity".

Moreover, natural as well as legal persons, who are not members of the water company, have to contribute to the company. Also organisational units, which do not have legal identity, and which benefit from the company's devices or pollute water also need to contribute. The starost constitutes the competent authority to determine the kind and amount of the presented fees and he/she makes appropriate decision.

The above presented situation leads to establishing civil law relation, in which the water company acts as creditor, and the natural persons, legal persons who are not members of the water company and organisational units, who do not have legal identity, act as debtors.

The basis of the presented relation will be an administrative decision. The company's claim of contribution will be based on the rules for executive proceeding in administration. It is essential to indicate, that a starost is not a part of the presented civil law relation ${ }^{28}$.

As it has been presented at the beginning of the research, in certain situations water companies can act to make a net profit. The services provided by a water company in the range of water provision, as well as waste water

B. Rakoczy, in: Prawo wodne..., p. 693.

28 Ibidem, p. 696. 
and sewage treatment, are based on the agreement made between the water company and the interested party.

\section{Authorities of the water company}

Similar to a trade company, the water company acts through its authorities, namely: the general meeting, management, and audit committee. It is important to say, that creation of the audit committee depends on the number of members of the water company. According to article 172 item 3 of the Water Law, the audit committee is created only if there are at least ten members in the company. Apart from the presented authorities, also other authorities, which are not presented in the article but which have its position in the company's Statute, can act within the water company..

Regarding the abovementioned, the authorities of the water company can be divided into three groups. The first group constitutes mandatory authorities, including the general meeting and administration. The second group consists of conditionally mandatory authorities including the audit committee. The third company constitutes facultative authorities which position does not result from the Act but from the Statute ${ }^{29}$.

\subsection{The general meeting}

The general meeting represents all the members of the water company and constitutes the highest authority of the company ${ }^{30}$. It supervises company's activity in all areas ${ }^{31}$ making decisions in form of acts.

The competences of the general meeting were enumerated by the Legislator in article 173 item 1 of the Water Law. According to presented regulation, the general meeting is obliged to: 1) enact the plan of work of the water company, as well as its budget. The management can be empowered to take loans or credits on behalf of the company up to the given amount; 2) enact the amount of contributions and other

B. Rakoczy, in: Prawo wodne..., p. 699.

M. Kałużny, Prawo wodne..., p. 552.

31 J. Szachułowicz, Prawo wodne..., p. 424. 
dues in favour of the company;2a) establish the price for water provided and sewage treatment, in case of activity which allows to make net profit; 3) election and dismissal of members of the management and audit committee; 4) consideration and acceptation of annual reports and giving vote of approval to the management; 5) passing acts on estate purchase or disposal, or to encumber the estate of the water company; 6) enact changes in the company's Statute; 7) pass acts on entering the water company to the union of water companies; 8) pass acts to join the water company with another water company or divide the water company into two or more companies; 9) pass act on termination of the water company and select loss adjusters; 10) approval of final calculations and reports by the water company's loss adjuster; 11) pass acts on issues presented by management or audit committee.

The presented catalogue is a closed catalogue, therefore it does not allow to presume the competence of the general meeting.

Moreover, by virtue of article 173 item 2 of the Water Law, the act by the general meeting on not giving the vote of approval to the management of the water company is synonymous to dismissal of the company's management. It should be said, that the presented regulation concerns the management of the company understood as authority, not its separate members ${ }^{32}$.

\subsection{Management board}

The management board of the water company is its executive authority. According to article 176 item 1 of the Water Law, its competences shall include: execution of acts passed by the general meeting, control of the company's activity, management of its assets, dealing with financial economy, and representing the company outside. Moreover, in item 6 of the given regulation, the Legislator allowed the management board of the water company to encumber members of the company with the costs of contribution or tasks that were not fulfilled in a given time.

Making current decisions concerning administration, employment, signing contracts and agreements, in the range of statutory activity, are

32 B. Rakoczy, in: Prawo wodne..., p. 701. 
all understood as management of company's activity. The administration of financial economy concerns obeying and implementing tax rules in company's activity which is based on the Act of 29 September 1994 on accounting ${ }^{33}$. The necessity of representation is associated with the fact that management board is the authority of the water company, a legal person that on the basis of article 64 of the Code of Civil Procedure ${ }^{34}$ has judicial rights, and on the basis of article 65 of the Code of Civil Procedure right to lawsuit procedures ${ }^{35}$.

Contrary to the general meeting, the competences of the management board of the water company were not included in a closed catalogue. The specification included in article 176 item 1 of the Water Law shall be recognised as an example, due to the fact that in item 4 of presented regulation, the Legislator introduced presumption of competences of the management board, in cases which were not disclaimed by other authorities ${ }^{36}$.

The issue of the number of the board members was not strictly regulated by the Legislator. In virtue of article 176 item 2 of the Water Law the management board can be a single or collegiate body. The Statute of the company specifies the number of members on the board. The essential issue is, the maximum number of members of the board was not specified by the Water Law, therefore it shall be presumed that the Statute can loosely specify it.

Regardless of the fact that the Legislator specified the turn of office of the management board as five years, article 176 item 3 of the Water Law, they also pointed out, that this issue could be regulated differently by the Statute of the company. It means, that one can invoke a statutory regulation, only if the turn of office of the board of the company has not been specified in the Statute.

The legal situation of the board members, when it comes to a turn of office, is obvious as all the members are selected at the same time. They play their own role for the entire time of their tenure, specified in the act or Statute. The Legislator did not, however, regulate the issue of tenure of the board member selected to play the role on the board once the board started the process of fulfilling its duties within the framework of the given tenure.

33 Journal of Laws of 2013, item 330 with amendments, consolidated text.

34 Journal of Laws of 2014, item 101 with amendments, consolidated text.

35 M. Kałużny, Prawo wodne..., p. 560.

36 B. Rakoczy, in: Prawo wodne..., p. 706. 


\section{Katarzyna Wesołowska}

It should be presumed, that in such a situation the tenure of the board member cannot be terminated later than the tenure of the board itself. The above shall be explained by literal interpretation of article 176 item 5 of the Water Law. The presented regulation regulates the tenure of the management board understood as a body, not as a member of the board understood as the guardian of the body ${ }^{37}$.

The view that the members of the water company's board can be elected only out of the members of the water company is explained in literature by referring to the Code of Commercial Companies. By article 201 item 3 of the presented act it was directly regulated that in a limited liability company persons from among, as well beyond the associates, could be elected. The presented regulation, according to J. Szachułowicz, indicates that only the Legislator can decide on the entrance into the body of company members of any persons from outside its membership. Lack of given regulations in the Water Law means only members of the company can enter the management board ${ }^{38}$.

A different opinion is presented by J. Sommer, who claims that only Statute of the water company can introduce limitations in the area of choosing people who are not members of the company to play roles on its management board ${ }^{39}$.

The author of the following research approves of J. Sommer's opinion. The Legislator did not regulate the matter objectively, which means that through analogy to the Code of the Comercial Companies, one cannot interpret the rules of the Water Law in a way which makes such severe limitations when it comes to the composition of the management board. It seems to appear, that the lack of proper regulation allows the associates of the water company to deal with legislation. De lege ferenda this matter should be regulated.

By virtue of article 176 item 5 of the Water Law, the management board can pass annunciations on behalf of the company. In the situation where there are not more than two persons on the board, only one member of the board is able to pass annunciations on behalf of the company,whereas,

37 M. Tyburek, Zarząd jako organ spótki wodnej, Przegląd Prawa Ochrony Środowiska 2009, No 1, p. 71.

38 Szachułowicz, Prawo wodne..., p. 430.

39 J. Sommer, in: Prawo wodne..., p. 429. 
in other cases, two members are required to pass it, if the Statue does not stipulate differently.

Due to the fact that the water company cannot establish the proxy, it is not possible to establish a way of representation which is based on mutual action of the board member and the proxy. An option to allow the board to act through the elected attorney is possible ${ }^{40}$.

\subsection{The audit committee}

The audit committee is a body which has control of the functions of the water company. According to article 177 item 1 of the Water Law, its duty is to control the company. The subject, range and frequency of control were not specified by the Legislator, who leaves this matter to the audit committee $^{41}$, The Legislator regulated the matter of control of financial economy of the company in detail. According to article 177 item 2 of the Water Law, it should be conducted at least once a year, before a general meeting, and at the results of control should be presented to the general meeting in a form of documented report.

The audit committee is a collegial body. The Statute defines the number of its members, however, in virtue of article 177 item 3 of the Water Law, there cannot be less than three members.

Similarly to the board, the audit committee is elected for five years, if the Statute does not state differently.

The Legislator in article 177 item 5 of the Water Law prohibited joining the role of the board member with the role of the audit committee member. The presented prohibition serves to reasonably administrate the assets of the company, which would not be possible in case in which these two roles are joined ${ }^{42}$.

Moreover, it should be mentioned that the vote of approval is not granted to the audit committee..$^{43}$

\footnotetext{
40 B. Rakoczy, in: Prawo wodne..., p. 706.

Ibidem, p. 710.

2 J. Szachułowicz, Prawo wodne..., p. 432

43 B. Rakoczy, in: Prawo wodne..., p. 711.
} 


\section{The supervision and control over the company.}

The control and supervision over water companies' activity was given to the starost. It should be emphasised, that the notion of "control" and "supervision" are not synonymous. Due to the fact, that these notions do not have legal definition, the notions formulated in the literature should be used.

The control should be defined as "activity serving to establish the actual state associated with the given subject (examination of its organisational state or behaviour), comparing its state with the postulated state on the basis of the criteria given by the law, eventually finds differences between these states, find their reasons and formulate recommendations aimed to eliminate and prevent these differences in the future ${ }^{44 "}$.

The supervision can be in turn understood as "statutory authorisation to use acts or activities joining the supervised subject, reviving its acts and activities ${ }^{45}$ ".

One of the forms of supervision realised by the starosts supervision over legal acts of the authorities of the water company. With the aim of allowing its realisation, the management board of the water company is obliged to give the acts of the company's bodies to the starost within seven days from its passing.

The starost checks the conformity of the passed regulations both with the current law, as well as with the Statute. In situation where the passed regulation is incompatible with law, the starost decides on its validity. However, he has to conduct a special proceeding to check if the regulation is certainly not valid. Moreover, while deciding on the proceeding, he can suspend performance of this resolution.

The starost is obliged to issue an administrative decision within the period of 30 days from the day of receiving the abovementioned

44 R. Giętkowski, in: Leksykon prawa administracyjnego. 100 podstawowych pojęc, ed. E. Bojanowski, K. Żukowski, Warszawa 2009, p. 128, see also W. Wyrążek, J. M. Izdebski, in: Leksykon administratywisty, ed. S. Wrzoska, A. Haładyj, M. Domagała, Radom 2013, p. 153.

45 R. Giętkowski, T. Bąkowski, in: Leksykon prawa administracyjnego..., p. 152. 
regulation. After that due date the starost cannot claim the invalidity of the incorrect regulation, but he/she can complain to the administrative court ${ }^{46}$.

According to article 179 item 4 of the Water Law, the water company which regulation was dismissed, can turn to the starost with motion to examine the issue, and after using this way, the water company may complain to administrative court.

In situation of constant violation of law or the Statute by the management board, the starost is authorised to decide on termination of the board. In such case, he/she is obligated to elect a person fulfilling the duties of the board. That person is obligated to call general meeting aimed at election of a new board. In situation where the general meeting does not elect a new board, the starost can decide to establish receivership of the water company.

Taking into consideration the above, it can be claimed that control executed by the starost constitutes the consequent control expost, not current control ex ante. Therefore, actions of the starost are based on control and evaluation of the passed regulations, which does not influence improvement of current activity of the company ${ }^{47}$.

\section{Termination of the water company}

To terminate a water company the Legislator accepted a certain course of action. Despite of the fact that termination of a water company which has certain assets, and specific goals and tasks, this regulation is very limited and consists of only 4 articles (article 181-184 of the Water Law) ${ }^{48}$.

According to the Water Law, there are two ways of termination of the water company. The first way is to call the general meeting about termination of the company. In this case, the reasons of termination of the company are not relevant, unless they breach on the operating law or inner law of the company - Statute. The Legislator did not specify the reasons of termination of the water company in above mentioned course of actions.

\footnotetext{
46 B. Rakoczy, in: Prawo wodne..., p. 713.

47 C. Kowalewski, Nadzór i kontrola nad spótkami wodnymi i zwiazkami wodnymi, in: Wybrane problemy prawa wodnego, ed. B. Rakoczy, Warszawa 2013, p. 251.

48 K. Kierzkowska, Rozwiq̨zanie spótki wodnej w prawie polskim, Przegląd Prawa Ochrony Środowiska 2012, No 2, p. 12.
} 
He left this issue to the general meeting's decision. For example, as a reason to terminate the water company by the general meeting we can treat: division of the company, the loos of legal water licence, or circumstances which cannot be in accordance with the goals for which the company was created $^{49}$.

The reasons to terminate the water company by the general meeting can be stipulated by the Statute of the company. However, lack of proper regulation still allows to terminate the company by the general meeting. Moreover, despite of listing specific reasons in the Statute, the company can be terminated in case of other circumstances, not mentioned in the Statute, or when the general meeting accepts the application for termination of the water company.

The second way to terminate the company is by decision of the starost. Contrary to the company termination done by the general meeting, the starost cannot make that decision freely. On the basis of article 181 item 2 of the Water Law, the presented way of termination of the water company is possible if: 1) the activity of the company violates law or statute 2) the time of receivership is finished and the general meeting has not elected new management board 3) the number of members (both natural and legal persons) is less than three. The presented catalogue of reasons, which can constitute the main reason of the starost's decision, is closed, which means that it cannot be extended. The presented reasons not have to happen together.

What is important, the water company cannot be terminated against the will of its associates. It should be highlighted that if any of the above mentioned premises happens, the starost can, but does not have to terminate the water company ${ }^{50}$.

As a comment to the first of the enumerated premises of termination of the company by the starost's decision, it should be indicated, that a subjective regulation is about validation of law or the Statute, which characterises itself by nuisance and high level of harmfulness. Termination of the company by the starost's decision on the basis of presented premise

49 J. Szachułowicz, Prawo wodne..., p. 437.

50 Judgement of the Voivodeship Administrative Court in Bydgoszcz of 3March 2009, II SA/Bd 905/08, Legalis. 
should take place only in case when it is the only way to restore activity agreeable with law $^{51}$.

Because the other two premises do not pose any doubts, the comment is not needed.

According to the opinion of the Voivodeship Administrative Court in Bydgoszcz ${ }^{52}$, the decision of the starost should be passed only after conduction of explanation proceeding, which is aimed at making real arrangements on the basis of detailed hearing of evidence with presence of both parties.

In case of decision on termination of the water company by the general meeting or when the decision of the starost on termination of the company is final, the water company is not automatically terminated but such a situation leads to liquidation proceeding. In term of this proceeding the company acts under its current name, plus the word "in liquidation" and keeps legal identity. The liquidator of the company can be a board member or another person elected by the general meeting. In situation where termination of the company is based on the decision of the starost, he/she is the body authorised to elect the liquidator.

The duty of the liquidator is to implement actions necessary to terminate the activity of the water company. Due to this, he/she obtains the rights and duties of the board.

What is important there can be one or more liquidators.

According to article 183 of the Water Law, the liabilities of a water company which is in the process of liquidation, are covered in order defined by the Legislator. First, the liabilites resulting from the employment obligations are covered. Next comes commitments associated with public donations, the costs of liquidation and other liabilities.

Because of lack of proper regulations concerning division of financial surplus after covering all the liabilities and eventual shortage, this issue is up to liquidator's decision. The surplus can be divided proportionally among the company's members, whereas shortage can be covered by them ${ }^{53}$.

Competences to pass the proper regulation are given to the starost. The motion can be passed only after receiving the resolution from the general

51 J. Sommer, in: Prawo wodne..., p. 429.

52 Judgement of the Voivodeship Administrative Court in Bydgoszcz of 3 March 2009, II SA/Bd 905/08, Legalis.

53 J. Szachułowicz, Prawo wodne..., p. 440. 
meeting of the water company being in liquidation, about acceptance of liquidator's final accounts and reports.

\section{The association of water companies}

The Water Law allows for the possibility of connecting water companies into one association which would have broader organisational structure. This would enable connecting economic, technical and organisational resources to better fulfil the tasks of water companies ${ }^{54}$.

In the Polish law, the associations of the water companies were not regulated differently than the water companies themselves. Special regulations about water companies are used to do it. However, the rights and duties of the starost towards water companies, in relation to associations of water companies are executed by the marshal of the voivodship. The broader territorial range of activity of the water companies association justifies it ${ }^{55}$.

The association of the water companies is a "legal entity", separate from the water companies which are part of it. Similarly to the water company, the association of water companies has to consist of at least 3 members 3 water companies. It also has its own separate bodies: the general meeting, management board and audit committee.

\section{Conclusion}

The water companies have characteristics which can make them efficient tools to solve particular problems of water economy, not only in local or regional range, but also countrywide or even internationally. Taking into consideration the objectives, for which water companies are created they constitute atopic which could be very interesting for the society ${ }^{56}$.

Ibidem, p. 441.

55 B. Rakoczy, in: Prawo wodne..., p. 681.

56 R. Paczuski, Spótki wodne - cele, zadania, prawne podstawy organizacji ..., p. 49-50. 
Despite the fact that the Water Act of 1922, which was based on the then modern, European regulations completely regulated the water companies. The regulations concerning water companies in the following acts were not so detailed. It was caused by the ideology of the system operating in the Polish People's Republic at that time. The current act - the Water Law, was passed after the political changes which took place in 1989. That act repeats imperfect solutions and law regulations of the previous acts ${ }^{57}$.

This situation results in a terse and often not precise regulation on water companies in operating law in Poland, which is not adjusted to changing economic conditions, or do not allow to fully use the tool which is the water company.

\section{Bibliography}

Giętkowski R., in: Leksykon prawa administracyjnego. 100 podstawowych pojęć, ed. E. Bojanowski, K. Żukowski, Warszawa 2009.

Kałużny M., Prawo wodne. Komentarz, Warszawa 2012.

Kierzkowska K., Rozwiązanie spótki wodnej w prawie polskim, Przegląd Prawa Ochrony Środowiska 2012, No 2.

Kowalewski C., Nadzór i kontrola nad spótkami wodnymi i zwiqzzkami wodnymi, in: Wybrane problemy prawa wodnego, ed. B. Rakoczy, Warszawa 2013.

Paczuski R., Prawo ochrony środowiska, Bydgoszcz 2000.

Paczuski R., Spótki wodne - cele, zadania, prawne podstawy organizacji oraz perspektywy ich rozwoju w kontekście zachodzacych zmian, Torun 2006.

Paczuski R., Spótki wodne. Historia. Podstawy prawne dziatania. Nowe tendencje, Warszawa 1989.

Rakoczy B., in: Prawo wodne. Komentarz, ed. B. Rakoczy, Warszawa 2014.

Sommer J., in: Prawo wodne. Komentarz, ed. J. Rotko, Wrocław 2002.

Szachułowicz J., Prawo wodne. Komentarz, Warszawa 2013.

Tyburek M., Zarząd jako organ spótki wodnej, Przegląd Prawa Ochrony Środowiska 2009, No 1.

Wielka encyklopedia prawa, Warszawa 2005.

Wyrążek W., Izdebski J. M., in: Leksykon administratywisty, ed. S. Wrzoska, A. Haładyj, M. Domagała, Radom 2013.

\section{Email}

kasiakierzkowska@gmail.com

57 Ibidem, p. 39-40. 